\title{
An In Vitro Evaluation of the Silage Mixtures Containing Different Levels of White Mulberry Pomace and Meadow Grass
}

\author{
Yeliz KÖKSAL1, Bora BÖLÜKBAŞ2*, Zehra SELÇUK²
}

\author{
${ }^{1}$ Republic of Turkey Ministry of Agriculture and Forestry, Veterinary Control Central Research Institute, 06020, Ankara, Turkey \\ ${ }^{2}$ Ondokuz Mayıs University, Faculty of Veterinary Medicine, Department of Animal Nutrition and Nutritional Diseases, 55139, Samsun, \\ Turkey
}

\begin{abstract}
This study was conducted to determine the in vitro gas production (GP), organic matter digestibility (OMD), and energy values of ensiled white mulberry pomace (WMP), meadow grass (MG), and the mixtures of the two crops at three different ratios. The silages in WMP/MG mixtures containing 100, 75, 50, 25, and $0 \%$ WMP were evaluated by using of $\mathrm{ANKOM}{ }^{\mathrm{RF}} \mathrm{GP}$ system. It was observed that increasing levels of WMP in the silages enhanced GP. Whereas the OMD value of WMP silage was highest (53.27\%) among all silages, MG silage was the lowest (47.83\%). Higher ME, NEL, and OMD values were obtained in WMP and MG mixture silage at a ratio of 75:25 compared with the other mixtures. The results indicated that the OMD, ME, NEL, and non-fiber carbohydrate values were positively correlated with GP-24 $\mathrm{h}(\mathrm{r}=0.981, \mathrm{r}=0.966, \mathrm{r}=0.981$, and $\mathrm{r}=0.957$, respectively). The results of the study showed that the OMD and energy values of WMP100/MG silage were higher than the other silages. In addition, since ensiling of WMP with MG at different ratios will be resulted in increases in OMD and energy values of WMP/MG silages, incorporating unusual silages like WMP/MG silage into diets may provide a benefit to reduce in cost of livestock production.
\end{abstract}

Keywords: In vitro gas production, meadow grass silage, mulberry pomace silage, organic matter digestibility.

$* * *$

Farklı Düzeylerde Beyaz Dut Posası ve Çayır Otu İçeren Silaj Karışımlarının In Vitro Değerlendirilmesi

ÖZ

Bu çalışma silolanan beyaz dut posası (BDP), çayır otu (ÇO) ve iki ürünün üç farklı oranda karışımlarının in vitro gaz üretimi (GÜ), organik madde sindirilebilirliği (OMS) ve enerji değerlerinin belirlenmesi amacıyla yapılmıştır. $\% 100,75,50,25$ ve $\% 0$ BDP içeren $\mathrm{BDP} / \mathrm{ÇO}$ karışım silajları $\mathrm{ANKOM}^{\mathrm{RF}}$ gaz üretim sistemi kullanılarak değerlendirildi. Silajlarda artan BDP seviyelerinin gaz üretimini artırdığı görüldü. BDP silajının OMS değeri tüm silajlar arasında en yüksek iken, ÇO silajının en düşüktü (\%47.83). BDP/ÇO'nun 75:25 oranındaki karışım silajında diğer karışımlara göre daha yüksek ME, NEL ve OMD değerleri elde edildi. Sonuçlar OMS, ME, NEL ve selüloz olmayan karbonhidrat değerleri ile $\mathrm{GÜ}-24$ sa arasında pozitif korelasyonun olduğunu gösterdi $(\mathrm{r}=0.981$, $\mathrm{r}=0,966, \mathrm{r}=0.981$ and $\mathrm{r}=0.957$, sırasıyla). Çalışmanın sonuçları, BDP100/ÇO silajının OMS ve enerji değerlerinin diğer silajlara göre daha yüksek olduğunu göstermiştir. Ayrıca BDP'nın farklı oranlarda ÇO ile silolanması, $\mathrm{BDP} / \mathrm{C} O$ silajlarının OMS ve enerji değerlerinde artışa neden olacağından $\mathrm{BDP} / \mathrm{C} O$ silajı gibi geleneksel olmayan silajların rasyonlara dahil edilmesi hayvansal üretim maliyetinin düşürülmesine katkı sağlayabilir.

Anahtar Kelimeler: Çayır otu silajı, dut posası silajı, in vitro gaz üretimi, organik madde sindirilebilirliği.

To cite this article: Köksal Y. Bölükbass B. Selcuk Z. An In Vitro Evaluation of the Silage Mixtures Containing Different Levels of White Mulberry Pomace and Meadow Grass. Kocatepe Vet J. (2021) 14(3):309-315

Submission: 20.04.2021 Accepted: 06.08.2021 Published Online: 29.08.2021

ORCID ID; YK: 0000-0003-4943-3176 BB: 0000-0002-6060-4514 ZS: 0000-0002-0732-0192

*Corresponding author e-mail: bora.bolukbas@omu.edu.tr 


\section{INTRODUCTION}

Recently, many countries worldwide have focused on recycling industrial by-products to mitigate environmental pollution (Mirzaei-Aghsaghali et al. 2011). Mulberry pomace (MP) is a by-product of the production of mulberry juice such as jam, molasses, etc., and it is consists of stem and peel parts of the mulberry. It constitutes approximately $8 \%$ of the weight of the fresh mulberry taken into processing (Elmac1 and Altuğ 2002). In general, MP is either used as a soil enhancer or discarded in landfills which causes environmental pollution (Zhou et al. 2014).

Meadow grass (MG) is an important roughage used in ruminant nutrition. It can be used as fresh, hay, or silage in the diets. Due to lower soluble carbohydrate content, high buffer capacity, and lower energy value of fresh MG compared to fresh corn or sorghum results in some difficulties during ensiling (Keady et al. 2008). Several studies have been conducted to improve or stimulate silage fermentation by using readily fermentable carbohydrate sources and bacteria inoculants (Atalay and Kamalak 2018, Baytok and Muruz 2003, O'Kiely and Moloney 1994). It has been reported that Gleditsia triacanthos that was carbohydrate-rich honey locust and added to MG silage material at the different levels, caused an increase in organic matter digestibility of MG silage (Güven and Kamalak 2011). When the addition of Gleditsia triacanthos to silage material at the level of 6 $\%$, metabolizable energy and organic matter digestibility values of silage increased by 8.76 and $11.87 \%$, respectively. Atalay and Kamalak (2018) investigated the effect of the addition of carob (Ceratonia siliqua) fractures at the level of $0,1.5,3$, 4.5 , and $6 \%$ to MG silage and reported that in vitro gas production value increased as the amount of carob fractures (Ceratonia siliqua) added to the silages at increasing levels.

In vitro cumulative gas production for evaluation of ruminant feeds has provided a measure of organic matter digestibility and fermentation kinetics of feeds (Storm et al. 2012). It can be used to estimate the energy values of feedstuffs such as straw (Selcuk et al. 2016), silage (Salman et al. 2018), agro-industrial byproducts (Mirzaei-Aghsaghali et al. 2011), and tropical feeds (Krishnamoorthy et al. 1995).

Although some vegetable and fruit pomaces such as tomato, orange, or apple are occasionally used in animal nutrition, it is not very common to utilize these sources in diets. However, there is a worldwide shortage of supplying roughage for animal nutrition, and also, traditional diet ingredients of ruminants are generally expensive. Hence, this study was conducted to determine the in vitro gas production (GP), organic matter digestibility (OMD), and energy values of the silages in white mulberry pomace WMP/MG mixtures containing 100, 75, 50, 25, and 0\% WMP.

\section{MATERIALS and METHODS}

\section{Silages}

The WMP100/MG, WMP75/MG, WMP50/MG, WMP25/MG, and WMP0/MG silages containing $100,75,50,25$, and $0 \%$ WMP, respectively, were evaluated by the use of ANKOM ${ }^{\mathrm{RF}}$ GP system. The WMP/MG mixture silages ensiled from WMP and MG were presented in Table 1. Nutrient composition of the silages packed into laboratory mini-silos (glass jars) and stored for 60-d fermentation were documented in detail in the study conducted by Köksal (2020). Dry matter, ash, crude protein, ADF, NDF contents of silage materials were 30.0, 7.71, $12.96,36.73,61.69 \%$ for $\mathrm{MG}$, and 26.49, 3.85, 11.28, $27.72,34.34$ for WMP, respectively. NFC (Nonfibrous carbohydrate) values of the silages were calculated using the equation of NRC (2001).

$\mathrm{NFC} \%=100-(\mathrm{NDF} \%+\mathrm{CP} \%+\mathrm{EE} \%+\mathrm{Ash} \%)$

Table 1. The silages ensiled from WMP and MG

\begin{tabular}{lcc}
\hline Silages & WMP\% & MG\% \\
\hline WMP100/MG & 100 & 0 \\
WMP75/MG & 75 & 25 \\
WMP50/MG & 50 & 50 \\
WMP25/MG & 25 & 75 \\
WMP0/MG & 0 & 100 \\
\hline
\end{tabular}

WMP: White mulberry pomace, MG: Meadow grass 


\section{In vitro Gas Production System}

Rumen fluid for $\mathrm{ANKOM}{ }^{\mathrm{RF}}$ gas production system, used in the study for measuring in vitro gas production, was collected from adult cows slaughtered at Florya Slaughterhouse in Samsun, Turkey. Rumen fluid was collected and transferred to the laboratory in a thermos at $39{ }^{\circ} \mathrm{C}$ under $\mathrm{CO}_{2}$ presence. Each unit of the system consisted of a 250 $\mathrm{mL}$ glass bottle equipped with an attached module that has wireless communication with the computer. The buffer solutions were prepared according to Menke and Steingass (1988). The prepared buffer solution was firstly warmed and then mixed with rumen fluid at 4:1. $100 \mathrm{~mL}$ of buffered rumen fluid was added to per warmed glass bottle, including $1 \mathrm{~g}$ of milled silage samples. After filling, all glass bottles were closed and placed into a water bath at $39 \pm 0.5$ ${ }^{\circ} \mathrm{C}$. Preparation of incubation media and the incubation procedure was carried out under anaerobic conditions up to $96 \mathrm{~h}$ at $39 \pm 0.5^{\circ} \mathrm{C}$. After incubation, the cumulative pressure values of silages at $0,4,8,16$, $24,48,72$, and $96 \mathrm{~h}$ were converted to $1 \mathrm{~mL}$ of gas at standard pressure and temperature (Menke and Steingass 1988). The equations used to estimate the OMD and the energetic feed value were given below:

$\mathrm{ME}(\mathrm{MJ} / \mathrm{kg} \mathrm{DM})=2.2+0.136 \mathrm{GP}+0.057 \mathrm{CP}+0.0029 \mathrm{EE}^{2}$

OMD $\%=148.8+8.89 \mathrm{GP}+4.5 \mathrm{CP}+0.651 \mathrm{~A}$

$\mathrm{NEL}(\mathrm{MJ} / \mathrm{kg} \mathrm{DM})=0.1149 \mathrm{GP}+0.0054 \mathrm{CP}+0.0139 \mathrm{EE}-0.0054 \mathrm{~A}-0.36$

GP: $24 \mathrm{~h}$ net gas production $(\mathrm{mL} / \mathrm{gDM})$

$\mathrm{CP}$ : Crude protein $(\mathrm{g} / \mathrm{kg} \mathrm{DM})$

EE: Ether extract $(\mathrm{g} / \mathrm{kg} \mathrm{DM})$

A: Ash (g/kg DM)

\section{Statistical Analysis}

According to the result of the Shapiro-Wilk test, all variables showed normal distribution. Levene test was performed to variance homogeneity test. It was determined that variances in all variables were homogeneous. One-way analysis of variance was used for comparison of the groups, and Tukey test was used to determine the differences among groups. The pairwise relationships among variables were evaluated by performing Pearson correlation analysis among variables within and between groups. SPSS (2012) statistical package program was used for statistical analysis.

\section{RESULTS}

Whereas the NFC value of fresh WMP was $39.05 \%$, the NFC value of fresh MG was 14.81\%. NFC contents of WMP100/MG, WMP75/MG, WMP50/MG, WMP25/MG and WMP0/MG silages were 27.54, 30.41, 24.36, 19.07 and $12.58 \%$, respectively. The GP profiles of all silages were shown in Table 2. There were differences in GP values $(\mathrm{P}<0.05)$ among the silages throughout the incubation period $(6,24,48 \mathrm{~h}$, and $96 \mathrm{~h})$. In all incubation periods, WMP0/MG silage had the lowest GP value, while WMP100/MG silage had the highest $(\mathrm{P}<0.05)$. It was observed that increasing levels of WMP in the mixtures enhanced GP.

The estimated parameters (OMD, ME, and NEL) were presented in Table 3. In vitro OMD of WMP100/MG silage $(53.27 \%$ of DM) was highest among all silages, whereas WMP0/MG silage $(47.83 \%$ of $\mathrm{DM})$ had the lowest digestibility. ME (8.27 $\mathrm{MJ} \mathrm{kg}^{-1} \mathrm{DM}$ ) and NEL (4.56 $\mathrm{MJ} \mathrm{kg}^{-1} \mathrm{DM}$ ) values of WMP100/MG silage were the highest, whereas ME (6.51 MJ kg-1 DM) and NEL values (3.07 MJ kg-1 DM) of WMP0/MG silage were the lowest among all silages $(\mathrm{P}<0.05)$. WMP75/MG silage had higher $(\mathrm{P}<0.05) \mathrm{ME}, \mathrm{NEL}$, and OMD than those of other silage mixtures.

The correlation parameters were presented in Table 4. The results indicated that the OMD, ME, NEL, and NFC values were positively correlated with GP-24h $(r=0.981, r=0.966, r=0,981$, and $r=0957$, respectively, while the ADF ( $r=-0.871)$, NDF ( $r=-0.966)$ contents of the silages were negatively correlated with the GP24h. Furthermore, when the MP level increased in the silages, NFC, OMD, ME, and NEL values increased $(\mathrm{P}<0.01)$. 
Table 2. In vitro gas production volumes (mL/0.2 g dry matter) of silages at different incubation times

\begin{tabular}{lccccc}
\hline & WMP100/MG $x \pm$ & WMP75/MG & WMP50/MG $x \pm$ & WMP25/MG $x \pm$ & WMP0/MG \\
Hour & $S x$ & $x \pm S x$ & $S x$ & $S x$ & $x \pm S x$ \\
\hline $4 \mathrm{~h}$ & $7.30 \pm 0.19^{\mathrm{a}}$ & $7.05 \pm 0.48^{\mathrm{a}}$ & $4.99 \pm 0.30^{\mathrm{b}}$ & $3.62 \pm 0.14^{\mathrm{c}}$ & $0.33 \pm 0.07^{\mathrm{d}}$ \\
$8 \mathrm{~h}$ & $10.48 \pm 0.10^{\mathrm{a}}$ & $9.39 \pm 0.18^{\mathrm{b}}$ & $6.93 \pm 0.06^{\mathrm{c}}$ & $4.88 \pm 0.14^{\mathrm{d}}$ & $3.85 \pm 0.21^{\mathrm{e}}$ \\
$16 \mathrm{~h}$ & $19.41 \pm 0.11^{\mathrm{a}}$ & $19.37 \pm 0.29^{\mathrm{a}}$ & $15.34 \pm 0.17^{\mathrm{b}}$ & $13.43 \pm 0.30^{\mathrm{c}}$ & $11.03 \pm 0.13^{\mathrm{d}}$ \\
$24 \mathrm{~h}$ & $30.81 \pm 0.23^{\mathrm{a}}$ & $30.21 \pm 0.15^{\mathrm{a}}$ & $27.31 \pm 0.20^{\mathrm{b}}$ & $25.14 \pm 0.004^{\mathrm{c}}$ & $23.00 \pm 0.24^{\mathrm{d}}$ \\
$48 \mathrm{~h}$ & $38.09 \pm 0.10^{\mathrm{a}}$ & $34.90 \pm 0.09^{\mathrm{b}}$ & $33.49 \pm 0.14^{\mathrm{c}}$ & $32.62 \pm 0.19^{\mathrm{d}}$ & $31.53 \pm 0.07^{\mathrm{e}}$ \\
$72 \mathrm{~h}$ & $39.63 \pm 0.18^{\mathrm{a}}$ & $36.95 \pm 0.18^{\mathrm{b}}$ & $35.96 \pm 0.19^{\mathrm{c}}$ & $34.52 \pm 0.22^{\mathrm{d}}$ & $32.90 \pm 0.12^{\mathrm{e}}$ \\
$96 \mathrm{~h}$ & $39.68 \pm 0.26^{\mathrm{a}}$ & $36.99 \pm 0.14^{\mathrm{b}}$ & $35.96 \pm 0.15^{\mathrm{c}}$ & $34.55 \pm 0.18^{\mathrm{d}}$ & $32.92 \pm 0.15^{\mathrm{e}}$ \\
\hline
\end{tabular}

WMP: White mulberry pomace, MG: Meadow grass

Means in the same line having different superscripts differ significantly $(\mathrm{P}<0.05)$

Table 3. Estimated parameters of silages at $24 \mathrm{~h}$ gas production

\begin{tabular}{lccccc}
\hline Item & WMP100/MG & WMP75/MG & WMP50/MG & WMP25/MG & WMP0/MG \\
& $x \pm S x$ & $x \pm S x$ & $x \pm S x$ & $x \pm S x$ & $x \pm S x$ \\
\hline OMD & $53.27 \pm 0.20^{\mathrm{a}}$ & $51.99 \pm 0.14^{\mathrm{b}}$ & $51.14 \pm 0.18^{\mathrm{c}}$ & $49.52 \pm 0.04^{\mathrm{d}}$ & $47.83 \pm 0.21^{\mathrm{e}}$ \\
ME & $8.27 \pm 0.03^{\mathrm{a}}$ & $7.66 \pm 0.02^{\mathrm{b}}$ & $7.32 \pm 0.02^{\mathrm{c}}$ & $6.86 \pm 0.00^{\mathrm{d}}$ & $6.51 \pm 0.03^{\mathrm{e}}$ \\
NEL & $4.56 \pm 0.02^{\mathrm{a}}$ & $4.14 \pm 0.01^{\mathrm{b}}$ & $3.81 \pm 0.02^{\mathrm{c}}$ & $3.39 \pm 0.00^{\mathrm{d}}$ & $3.07 \pm 0.02^{\mathrm{e}}$
\end{tabular}

WMP: White mulberry pomace, MG: Meadow grass, OMD: Organic matter digestibility, ME: metabolisable energy, NEL: net energy lactation

Means in the same line having different superscripts differ significantly $(\mathrm{P}<0.05)$

Table 4. The correlations between some parameters of the silages

\begin{tabular}{|c|c|c|c|c|c|c|c|c|c|}
\hline & OMD & $\mathrm{ME}$ & NEL & $\mathrm{GP}_{24 \mathrm{~h}}$ & $\mathrm{ADF}$ & $\mathrm{NDF}$ & $\mathrm{CP}$ & $\mathrm{NFC}$ & WMP level \\
\hline OMD & & $* *$ & $* *$ & $* *$ & $* *$ & $* *$ & NS & $* *$ & $* *$ \\
\hline $\mathrm{ME}$ & 0.981 & & $* *$ & $* *$ & $* *$ & $* *$ & NS & $* *$ & $* *$ \\
\hline NEL & 0.989 & 0.998 & & $* *$ & $* *$ & $* *$ & NS & $* *$ & $* *$ \\
\hline $\mathrm{GP}_{24 \mathrm{~h}}$ & 0.981 & 0.966 & 0.981 & & $* *$ & $* *$ & $\mathrm{NS}$ & $* *$ & $* *$ \\
\hline $\mathrm{ADF}$ & -0.885 & -0.956 & -0.936 & -0.871 & & $* *$ & NS & $* *$ & $* *$ \\
\hline $\mathrm{NDF}$ & -0.964 & -0.914 & -0.938 & -0.966 & 0.766 & & NS & $* *$ & $* *$ \\
\hline $\mathrm{CP}$ & -0.375 & 0.410 & 0.368 & 0.200 & -0.440 & -0.238 & & NS & NS \\
\hline NFC & -0.922 & 0.866 & 0.898 & 0.957 & -0.709 & -0.984 & 0.061 & & $* *$ \\
\hline WMP level & 0.985 & 0.993 & 0.997 & 0.983 & -0.310 & -0.948 & 0.339 & 0.913 & \\
\hline
\end{tabular}

OMD: Organic matter digestibility, ME: Metabolizable energy, NEL: Net energy lactation, GP $24 \mathrm{~h}$ : Gas production at 24 h, ADF: Acid detergent fiber, NDF: Neutral detergent fiber, CP: Crude protein, NFC: Non fiber carbohydrate, MP: White mulberry pomace, NS: none significant, $* * \mathrm{P}<0.01$ 


\section{DISCUSSION}

Ruminants can effectively utilize carbohydrate-rich agro-industrial by-products thanks to rumen microorganisms. These carbohydrates are fermented by microorganisms and converted into energy sources such as glucose and volatile fatty acids. Since fresh fruits are seasonal, ensiling their pomaces with conventional roughages and incorporating them into ruminant diets can be an effective method. Although numerous studies have been conducted on the nutritional content of WMP, little is known about its ensiled properties (Zhou et al. 2012). Due to the scarcity of data on WMP silage or the partial use of WMP as a silage material, results from other agroindustrial by-products were used to compare digestibility, GP, and energy.

In vitro GP is an effective parameter commonly used to predict the potential nutritional value of feedstuffs. The GP volume of feeds after $24 \mathrm{~h}$ incubation is used to estimate digestibility, ME, and NEL values (Menke and Steingass 1988). The feedstuffs typically produce more than $80 \%$ of total GP in the first $24 \mathrm{~h}$ of incubation (Tagliapietra et al. 2015). In accordance with this information, $70-80 \%$ of total GP in all silages is produced within the first $24 \mathrm{~h}$. In the current study, the highest GP was in WMP100/MG silage during all incubation periods, and the lowest GP was in WMP0/MG silage. Moreover, GP increased in direct proportion to silage WMP levels. The increased GP by adding pomaces agrees with previous reports (Besharati et al. 2017, Canbolat et al. 2010) and could be explained by the fact that the higher silage NFC content and increased carbohydrate fermentation. Feeds with a high NFC level produce more gas because rumen microbes can ferment the soluble fractions of the feedstuff more easily (Blümmel and Becker 1997). Additionally, increased GP could be linked to improved silage quality (Hetta et al. 2007), which would also influence microbial access to fermentable carbohydrates in the rumen.

Zhou et al. (2012) reported that the GP of WMP silage at the $48 \mathrm{~h}$ was $18.7 \mathrm{~mL} / 0.2 \mathrm{~g} \mathrm{DM}$, which was relatively lower than those found in the current study $(38.09 \mathrm{~mL} / 0.2 \mathrm{~g} \mathrm{DM})$. These different results might be attributed to two possible reasons: the difference in the nutrient content of the ensiled fresh material and the ensiling method used. The gas volume of WMP100/MG (30.81 mL/0.2 g DM) after $24 \mathrm{~h}$ of incubation was comparable to the values reported by Kara et al. (2018) for pomegranate pomace $(29.29 \mathrm{~mL} / 0.2 \mathrm{~g} \mathrm{DM})$ and apple pomace (32.44 mL/0.2 g DM). Despite the similarities in gas productions between the two studies, our findings indicate that WMP100/MG silage had higher OMD (53.27\%), ME (8.27 MJ/kg DM), and NEL (4.56 $\mathrm{MJ} / \mathrm{kg} \mathrm{DM}$ ) values than pomegranate and apple pomace reported by Kara et al. (2018).
Pirmohammadi et al. (2006) and Ülger et al. (2018) reported that in vitro OMD values of apple pomace silages were 57.5 and $62.32 \%$, respectively. Ülger et al. (2018) stated that the ME and NEL values of apple pomace silage were 8.37 and $4.18 \mathrm{MJ} / \mathrm{kg} \mathrm{DM}$, which was similar to the value of WMP100/MG silage in our study. The result of the present work for OMD value was also similar to those of Pirmohammadi et al. (2006). Ülger et al. (2018) reported that ME and NEL values of corn silage were the lowest among the apple pomace/corn silage mixtures, which was similar to our result for $\mathrm{MP0} / \mathrm{MG}$ silage. Furthermore, the silages in WMP/MG mixtures containing 100, 75, 50, 25, and $0 \%$ WMP resulted in a decrease in the OMD and energy values of the silages. Many factors such as differences in evaluated materials as a pomace or silage, varied processing methods of fruits, and nutrient contents of pomaces may explain differences in OMD, ME, and NEL values between this study and others. However, the differences in OMD and energy values of the evaluated silages in the current study were attributed to the difference in their nutritional components caused by the different levels of WMP and MG.

Lactic acid bacteria (LAB) can convert water-soluble carbohydrates into organic acids (primarily lactic acid) during the ensiling process, allowing for rapid $\mathrm{pH}$ reduction of silage. A low $\mathrm{pH}$ and anaerobic environment can inhibit the activities of undesirable microbes and preserve nutrients (Chen et al. 2020). Since pomaces have high water-soluble carbohydrate contents, ensiling them with roughages that have high buffer capacity increases silage quality and nutritional values (Ke et al. 2015). Canbolat et al. (2010) reported that increasing levels of grape pomace added to alfalfa silage increased the OMD and ME values of the silages. In accordance with this study, we found that the GP, OMD, ME, and NEL values increased with the elevated levels of MP in the silage. After $96 \mathrm{~h}$ of incubation, WMP75/MG silage, which contains a higher proportion of WMP, produced more gas and had higher OMD, ME, and NEL values than WMP50/MG and WMP25/MG silages. Our findings were consistent with those of some studies (Kara et al. 2018, Zhou et al. 2012), which indicated that pomaces are fermented quickly and have the potential to produce more gas than several roughages.

There is a strong relationship between the nutrient content of feeds and in vitro cumulative GP. Getachew et al. (2004) reported that the NFC content of feeds was positively correlated with GP and estimated parameters (OMD and ME), whereas feed $\mathrm{CP}$ and NDF levels were negatively correlated. Similarly, we found a positive correlation between GP and NFC, ME, OMD, NEL values and a negative correlation with $\mathrm{NDF}$ and $\mathrm{ADF}$ values. However, there were no correlations with CP. According to Canbolat and Karaman (2009), increased NDF and ADF contents, which were difficult to dissolve in the 
rumen, reduced gas production and OMD by limiting microbial fermentation. As the WMP increased in the silages in the current study, the NDF and ADF content of silages decreased. This may explain the negative correlation between GP and NDF, ADF contents, and the positive correlation between GP and WMP level.

\section{CONCLUSION}

The study results showed that WMP increased OMD and energy values in silage mixtures. Therefore, incorporating unusual and economical silages like $\mathrm{WMP} / \mathrm{MG}$ mixture into ruminant diets may provide a benefit to reduce livestock production costs.

Ethical Statement: This study does not present any ethical concerns.

Conflict of Interest: The authors declared that there is no conflict of interest.

\section{REFERENCES}

Atalay Aİ, Kamalak A. Effect of Locust Bean Fracture on $\dot{I}_{n}$ vitro and In situ Degradation of Grass Silage. Iğdır Univ. Fen Bilim. Enst. Derg. 2018;8(4): 361-7.

Baytok E, Muruz H. The effects of formic acid or formic acid plus molasses additives on the fermentation quality and DM and ADF degradabilities of grass silage. Turkish J. Vet. Anim. Sci. 2003;27(2): 425-31.

Besharati M, Shafipour N, Abdi E, Nemati Z. Effects of supplementation alfalfa silage with molasses, orange pulp and Lactobacillus buchneri on in vitro dry matter digestibility and gas production. J. Biosci. Biotechnol. 2017;6(1): 43-7.

Blümmel M, Becker K. The degradability characteristics of fiftyfour roughages and roughage neutral-detergent fibres as described by in vitro gas production and their relationship to voluntary feed intake. Br. J. Nutr. Cambridge University Press; 1997;77(5): 757-68.

Canbolat Ö, Kalkan N, Karaman S, Filya I. The investigation of possibility of grape pomace as carbohydrate source in alfalfa silages. Kafkas Univ Vet Fak. 2010;16(2): 269-76.

Canbolat Ö, Karaman Ş. Comparison of in vitro Gas Production, Organic Matter Digestibility, Relative Feed Value and Metabolizable Energy Contents of Some Legume Forages. J. Agric. Sci. 2009;15(02): 188-96.

Chen L, Qu H, Bai S, Yan L, You M, Gou W, Li P, Gao F. Effect of wet sea buckthorn pomace utilized as an additive on silage fermentation profile and bacterial community composition of alfalfa. Bioresour. Technol. 2020;314: 123773

Elmacı Y, Altuğ T. Flavour evaluation of three black mulberry (Morus nigra) cultivars using GC/MS, chemical and sensory data. J. Sci. Food Agric. 2002;82(6): 632-5.

Getachew G, Robinson PH, DePeters EJ, Taylor SJ. Relationships between chemical composition, dry matter degradation and in vitro gas production of several ruminant feeds. Anim. Feed Sci. Technol. 2004;111(1-4): $57-71$.
Güven İ, Kamalak A. Gladiçya Meyvesinin Çayırotu Silajında Kullanımı. Black Sea J. Eng. Sci. 2011;4(1): 22-8.

Hetta M, Cone JW, Bernes G, Gustavsson A-M, Martinsson $\mathbf{K}$. Voluntary intake of silages in dairy cows depending on chemical composition and in vitro gas production characteristics. Livest. Sci. 2007;106(1): 47-56.

Kara K, Guclu BK, Baytok E, Aktug E, Oguz FK, Kamalak A, Atalay AI. Investigation in terms of digestive values, silages quality and nutrient content of the using pomegranate pomace in the ensiling of apple pomace with high moisture contents. J. Appl. Anim. Res. 2018;46(1): 1233-41.

Ke WC, Yang FY, Undersander DJ, Guo XS. Fermentation characteristics, aerobic stability, proteolysis and lipid composition of alfalfa silage ensiled with apple or grape pomace. Anim. Feed Sci. Technol. 2015;202: 12-9.

Keady TWJ, Kilpatrick DJ, Mayne CS, Gordon FJ. Effects of replacing grass silage with maize silages, differing in maturity, on performance and potential concentrate sparing effect of dairy cows offered two feed value grass silages. Livest. Sci. 2008;119(1-3): 1-11.

Köksal Y. Dut posasının çayır otu ile silolanmasının silaj kalitesine ve sindirilebilirliği üzerine etkilerinin araştırılması. PhD thesis, Ondokuz Mayis University, Health Science Institute, Samsun, 2020.

Krishnamoorthy U, Soller H, Steingass H, Menke KH. Energy and protein evaluation of tropical feedstuffs for whole tract and ruminal digestion by chemical analyses and rumen inoculum studies in vitro. Anim. Feed Sci. Technol. 1995;52(3-4): 177-88.

Menke KH, Steingass $\mathbf{H}$. Estimation of the energetic feed value obtained from chemical analysis and gas production using rumen fluid. Anim. Res. Dev. 1988;28: 7-55.

Mirzaei-Aghsaghali A, Maheri-Sis N, Mansouri H, Razeghi ME, Shayegh J, Aghajanzadeh-Golshani A. Evaluating nutritional value of apple pomace for ruminants using in vitro gas production technique. Ann. Biol. Res. 2011;2: 100-6.

NRC. Nutrient Requirements of Dairy Cattle. 7th rev. ed., The National Academic Press, Washington DC, USA. 2001.

O'Kiely P, Moloney AP. Silage characteristics and performance of cattle offered grass silage made without an additive, with formic acid or with a partially neutralised blend of aliphatic organic acids. Irish J. Agric. Food Res. 1994; 25 39.

Pirmohammadi R, Rouzbehan Y, Rezayazdi K, Zahedifar M. Chemical composition, digestibility and in situ degradability of dried and ensiled apple pomace and maize silage. Small Rumin. Res. 2006;66(1-3): 150-5.

Salman M, Muruz H, Cetinkaya N, Selcuk Z, Kaya I. Effects of the addition of essential oils cumimaldehyde, eugenol, and thymol on the in vitro gas production and digestibility of alfalfa (Medicago sativa L.) silage. Turkish J. Vet. Anim. Sci. 2018;42(5): 395-401.

Selcuk Z, Cetinkaya N, Salman M, GENÇ B. The determination of in vitro gas production and metabolizable energy value of rice straw treated with exogenous fibrolytic enzymes. Turkish J. Vet. Anim. Sci. 2016;40(6): $707-13$.

SPSS (2012). IBM SPSS statistics for Windows, version 21.0. Armonk, NY: IBM Corp.

Storm IMLD, Louise A, Hellwing F, Nielsen NI, Madsen J. Methods for Measuring and Estimating Methane Emission from Ruminants. Animals. 2012;2: 160-83.

Tagliapietra F, Cattani M, Guadagnin M, Haddi ML, Sulas L, Muresu R, Squartini A, Schiavon S, Bailoni L. Associative effects of poor-quality forages combined with food industry by-products determined in vitro with an 
automated gas-production system. Anim. Prod. Sci. 2015;55(9): 1117-22.

Ülger I, Kaliber M, Ayaşan T, Küçük O. Chemical composition, organic matter digestibility and energy content of apple pomace silage and its combination with corn plant, sugar beet pulp and pumpkin pulp. S. Afr. J. Anim. Sci. 2018;48(3): 497-503.

Zhou B, Meng QX, Ren LP, Shi FH, Wei Z, Zhou ZM. Evaluation of chemical composition, in situ degradability and in vitro gas production of ensiled and sun-dried mulberry pomace. J. Anim. Feed Sci. 2012;21(1): 188-197

Zhou Z, Zhou B, Ren L, Meng Q. Effect of ensiled mulberry leaves and sun-dried mulberry fruit pomace on finishing steer growth performance, blood biochemical parameters, and carcass characteristics. PLoS One. 2014;9(1). 